\title{
ANALYSIS OF LEXICAL AND CONTEXTUAL MEANING IN RAEF'S SONG LYRIC OF THE PATH ALBUM AS THE HOLY QUR'AN VALUES
}

\author{
Risalatul Hasanah ${ }^{1}$ \\ ${ }^{1}$ English Teaching Learning Program, Tarbiyah Faculty, Institut Agama Islam Negeri Madura \\ (risa.madura@gmail.com) \\ Mosleh Habibullah ${ }^{2}$ \\ ${ }^{2}$ English Teaching Learning Program, Tarbiyah Faculty, Institut Agama Islam Negeri Madura \\ (moslehhabibulah@gmail.com)
}

\begin{abstract}
The Holy Qur'an is guidance to live, some of its meaning can be inserted into the lyric of the song, such as Raef's song lyrics. Three research focuses are proposed, i.e how are the lexical meaning, how are the contextual meanings, and what are the Holy Qur'an values consists of Raef's song lyric in The Path album. This study is a library. The data sources are Raef's song lyric of The Path album which consists of 12 lyrics of songs, and the Holy Qur'an values. The finding revealed that in the lexical analysis, the meaning of a word is varied, for example, the keyword of "words" in Peace and Blessing lexically means languages, utterances, promises, signals, and teachings. And contextually, the intended meaning of it is sunnah, then from those meanings it will relate to the Holy Qur'an value which supports the lyric of song, namely an-Nur (24): 54 which contains the value of Sunnah and the obligation to follow sunnah of Rasulullah, and it relates to the lyric of song when it also talks about the same thing. That kind of findings is also similar to the other analysis in all Raef's song lyrics of The Path album.
\end{abstract}

Keywords: Contextual Meaning; Holy Qur'an Values; Lexical Meaning; Raef's Song Lyrics

First Received:

(January 28, 2020)
Final Proof Received:

(March 20, 2020)

\section{INTRODUCTION}

Language, according to Krisdalaksana in Aminuddin, is arbitrary symbol system which is used by a people to interact, work together, and identify themselves (Aminuddin, 2008: 28) . As a system, one of its components is semantics. Semantics is one of the mayor subfields of linguistics (Jannedy, 1994: 5). It is defined as the study of the meaning of words and sentences (Jannedy, 1994: 216). It is also defined as the study of meaning (Lyons, 1995: 3). Meaning itself is not the simple word "meaning". It is highly complex, multifaceted phenomenon, and any complete explanation because the word "meaning" will have a wide range of contexts and distinguishable senses.

A word when used in a piece of text, will only have one meaning that matches through the text although it has many multiple choices in meaning. However, when this attempt to know the meaning of the word through the word meaning (or to be more precise lexical meaning) (Lyons, 1995: 33), the word will have many meanings (the meaning will vary). It 
occurs because in the lexical meaning (external meaning), based on Harimurti in Pateda, the meaning of the word will be free from its context and usage, and it also explained by Verhaar that a dictionary is an example for lexical meaning because every meaning in the dictionary are the lexical meaning of the word (Pateda, 2001: 119). Thus, every meaning that contained in the dictionary is the lexical meaning of the word.

But somehow with that multiple choice in the meaning of the word through lexical meaning, the consideration of taking only one meaning itself is based on the context (Dash, 2008). The contextual meaning appears as the result between statement and context (Pateda, 2001: 116). By contextual meaning, the understanding of the intended word and whole text will be clear and provide the necessary information. This lexical and contextual meaning is used to understand the meaning of the text deeply and correctly.

Lyric of the song has the same structure as poetry. It has rhythm, verse, rhyme, and stanza. It also has terms for critical analysis because every word in a lyric of a song has it's own meaning, as the explanation above, seeking the meaning of a word which stands alone will be the field of lexical meaning and can not be separated to that contextual meaning.

Holy Qur'an is a guidance for all human beings in the world. It is a revelation from Allah which was given to Prophet Muhammad SAW starting from Al-Fatihah to An-Nas (Biek, 2007: 461). Reading and comprehending the Holy Qur'an is necessary for all humans, especial Muslim. The Holy Qur'an has values that will guide the human to live in the world. Many things Allah explains in the Holy Qur'an even from the small thing (the way to walk) (al-Qur'an, Luqman: 31) to the big thing (prayer, state, law, etc). Human being, especially Muslim should allow it as a guidance, and fortunately, Raef, tried to explain the values of the Holy Qur'an through his album. So the people can easily understand the values of the Holy Qur'an and take the positive values of it through music which is joyful for them.

\section{LITERATURE REVIEW}

\section{Lexical Meaning}

Meaning is highly complex, the multifaceted phenomenon involving relationships between a language and the minds of its speakers, between a language and the world, and also between a language and the practical uses to which it is put (Jannedy, 1994: 219). A sentence which is the product of the words or phrases has meaning. Talking a lexeme, or dictionary-words, the noun lexeme relates to the words 'lexical' and 'lexicon' (Lyons, 1995: 47). The term lexical meaning is equivalent to term word meaning. Lexical meaning (semantic/external meaning) is the meaning of the word when it stands alone, and it is free from other aspects such as its usage and context (Pateda, 2001: 119). Lexical meaning will have the correlation to the dictionary because every meaning in the dictionary will be the example of lexical meaning. That definition is in line with Djajasudarma (2012: 53), the lexical meaning is the meaning of the word in the dictionary. When a word has a 
meaningful unit, it has to deal with the fact that a word sometimes has some meaning, then the same meaning sometimes combined with several words.

The necessary a word to have meaning, although it is only a word, different forms of the same lexeme will generally different in meaning (Pateda, 2001: 52). They have the same lexical meaning, but in respect of their grammatical meaning need a consideration, because they will be different. To clearer this fact, take a look at the example of 'flower' and 'flowers'. Those two words have the same lexical meanings but differ in respect of grammatical meaning. The word 'flower' is singular form, and the second 'flowers' is in the plural form when it is considered as a noun of a particular subclass. For further example, the differences among present, past, future, and even continues forms will also affect to the sentence meaning (a sentence is a composition of words and phrases). So, knowing the lexical meaning has to be considered to the grammatical equivalent of making a good sense of the sentence. Talking about grammatical equivalent that has to be considered in lexical meaning, it is also homonymy. Homonymy will also take a role in the ambiguity of the meaning (Pateda, 2001: 56).

\section{Contextual Meaning}

Contextual meaning (situational meaning) appears as the result between statements and context (Pateda, 2001: 116). Thus, the context has its role to give the meaning. Theory of contextual meaning is stated by J.R Firth and Malinowski. J.R Firth stated that the meaning of words cannot be separated with cultural environment and ecology of the speaker (Parera, 2004: 47). This statement was supported by Malinowski who stated that the word will not have meaning when it is separated from its context (Parera, 2004).

In understanding the actual meaning of words, the context has tremendous importance. This contextual meaning, will necessity to know the actual meaning of the word while a word has many variations of meaning. Through many multiple meanings of a word, a context has a responsibility to know the actual meaning of words (Dash, 2008: 21). Pateda classified many contexts in order to know the intended meaning of the keyword, such as people context, situational context, purposeful context, formal context, moody context, time context, place context, object context, and language context. Those contexts are used in order to know the meaning of the keyword based on what context relates to the keyword (Pateda, 2001: 116-118).

However, in another theory, which has different view in obtaining the contextual meaning of the keyword, Miller and Leacock classified context into two, they are local and topical context, but those two classifications are more or less sufficient in understanding the actual contextual meaning in a text. Thus, the classification in understanding it is local context, sentential context, topical context, and global context (Pateda, 2001: 22). These classifications are used in layering concept. Thus one by one classification, used in understanding the actual meaning of the word and by this layering concept gives more 
specific meaning in obtaining the meaning of the keyword because the analysis of obtaining the keyword is taken from the small part of the text to the general one.

Keyword in the center of that circle is the actual meaning of a word. Keyword is surrounded by 4 layers which necessary to seek the actual meaning of the word. Those four layers are the first circle is local context, it will be the center of attention as it can provide the most vital information to the contextual meaning of a word (Pateda, 2001: 2223). Thus, to obtain information of the keyword, local context used with the neighboring word (left word (LW) and right word (RW) of the keyword (KW)). However, the information from the local context is not enough to obtain the key word, thus the second layer is necessary to use. The second layer to obtain the actual meaning of the word is sentential context. It is used for retrieving the information from the sentence where the KW has taken place. The third layer is the topical context which is used to extract information from the topic of discussion if the local and sentential context fails to provide it. The last layer is global context, it will seek to acquire information from the extralinguistic world for deciphering the contextual meaning of the KW when the other contexts are not able to provide the necessary inputs.

\section{a. Local Context}

The local context is the immediate environment of the KW in a sentence where it has occurred, this immediate environment such as: preceding and succeeding words (Dash, 2008: 23). This local context will form a lexical block where conceptually, preceding (i.e., left) word (LW), the keyword (KW), and the immediately succeeding (i.e., right) word $(\mathrm{RW})(=\mathrm{LW}+\mathrm{KW}+\mathrm{RW}) . \mathrm{KW}$ in this lexical block as the main member while LW and RW as the supporting members.

\section{b. Sentential Context}

The sentential context refers to a sentence where the KW has occurred in that sentence (Dash, 2008: 26). This is used when the local context is not able to know the contextual meaning of the word or used when a set of two or three words maintains a special kind of relation although they are used at distant places within a sentence. This case mostly happens in the broken words, group verbs, idiomatic expression, and set phrases where the two constituents, despite their idiomatic or phrasal relations, are separated from one another to be located at distant places in the sentence.

\section{c. Topical Context}

The topical context refers to the topic of discussion on the content of a piece of text because finding the literal meaning of the KW often depends heavily on the topic which has a strong role to alter the etymological meaning of the KW (Dash, 2008: 27). For instance: the word 'shot' in English refers to 'firing', 'drinking', 'hitting a ball by bat', 'kicking a ball', 'putting a ball in the net', distance between a player and the hole', 'taking a snap', 'giving an injection', or 'making love'. 


\section{d. Global Context}

The last layer to know the contextual meaning of the KW, if the other layers cannot decipher the contextual meaning of the KW, the global context is used. Global context refers to extra-linguistic reality surrounding the linguistic acts undertaken by language users (Dash, 2008: 28).

\section{The Author's Biography}

Raef with the complete name Raef Haggag was born in Washington, D.C., United States of America, August 08, 1992. ("Biodata Raef termasuk Profil Pribadi \& Data Keluarga-WowKeren.com," 1992) His occupations are a singer, songwriter, and Computer Science Teacher at Montgomery County Public Schools (“Raef Haggag| LinkedIn," 2018). His genres of music are acoustic, rock, and folk ("Raef (singer)," 2018). His instruments are as vocalist and guitar under the label of Awakening Record.

While teaching, he wrote a music lyric and often performing at local coffee shops and busking at metro stations. He was introduced to the national stage after his trio rock band "Great Seneca" toured the United States of America as part of the "Voices for Change" initiative. Raef also joined the "Poetic Vision Tour", it is a band of traveling musicians and poets catering to the American Muslim community. Raef also did several Islamic covers of popular main-stream songs, attracting young listeners wanting a modern take on religious music.

Raef signed with Awakening Records and released his debut album The Path in 2014. The path album consists of 12 songs, they are: Peace \& Blessings, The Bright Moon (Tala'al Badru), So Real (feat. Maher Zain), You Are the One, Home, No One Knows but Me, The Path, Mawlaya, Call on Him, Freedom Ain't Free (feat. Nano Omar), Dream, You're There.

\section{The Holy Qur'an Value}

Value is the description of the beautiful, interesting, enchanted, and amazing thing which makes ones happy and wants to have it (Muhmidayeli, 2013: 101). Value is also always indicated to the quality (Muhmidayeli, 2013). Holy Qur'an is a guidance for all human beings in the world. It is a revelation from Allah which was given to Prophet Muhammad SAW starting from Al-Fatihah to An-Nas (Biek, 2007: 461).

\section{Previous Study}

The previous study in this research is by Ripta Permata Sari, the student of Universitas Islam Negari Sunan Gunung Jati in her thesis. She studied about "A Semantic Analysis on Maher Zain's Lyrics as Related to The Holy Qur'an Values." In her study, she found that Maher Zain's lyric "Thank You Allah" album contains the Islamic values. However, her study is different from the researcher's study. It is because she studies semantic analysis (lexical and contextual) meaning only based on Jhon Lyons theory, and the researcher study does not focus on Jhon Lyons theory. The differences also appear in 
the subject of study. The previous study researches of Maher Zain's lyric, but the researcher studies about Raef's song lyric.

\section{METHOD}

The researcher uses the qualitative approach. The kind of research used in this study is descriptive research. The subject of research in this study is Raef's song lyric in The Path album. The object of research in this study is the lexical and contextual meaning in the Raef's song lyric album. This research uses library research descriptive qualitative. The techniques of data collection that will be used by the researcher are: choosing the Raef's song lyric The Path album, reading and understanding that lyrics; choosing and selecting data dealing with each problem that will be investigating by giving underline; underlining a word in each lyric of song that will be analyzed; arranging systematically the obtaining data to investigate the lexical meaning of data; arranging systematically the obtaining data to investigate the contextual meaning of data; arranging systematically the obtaining data that have already found by lexical and contextual meaning to be related to the Holy Qur'an values. Then the data analyses in this research are: Prepare and Organize The Data for Analysis, Explore and Code The Data, Use Codes to Build Description and Theme, Represent and Report Findings, Interpret Findings, Validate The Accuracy of Findings.

\section{RESULTS AND DISCUSSION}

\begin{tabular}{|c|c|c|c|c|c|}
\hline No. & $\begin{array}{l}\text { Title of } \\
\text { Lyrics }\end{array}$ & $\begin{array}{l}\text { Word of } \\
\text { Lyrics }\end{array}$ & Lexical Meaning & Contextual Meaning & $\begin{array}{l}\text { Verses } \\
\text { Supporting } \\
\text { Lyrics }\end{array}$ \\
\hline 1. & $\begin{array}{l}\text { Peace and } \\
\text { Blessings }\end{array}$ & $\begin{array}{l}\text { His words are } \\
\text { here to help } \\
\text { us through } \\
\text { (L. 3) }\end{array}$ & $\begin{array}{l}\text { Languages, } \\
\text { utterances, } \\
\text { promises, signals, } \\
\text { or teachings }\end{array}$ & $\begin{array}{l}\text { LC: Spoken } \\
\text { SC: Spoken or teachings } \\
\text { TP: Spoken or teachings } \\
\text { GC: Sunnah }\end{array}$ & $\begin{array}{l}\text { An-Nur } \\
(24): 54\end{array}$ \\
\hline 2. & $\begin{array}{l}\text { The Bright } \\
\text { Moon }\end{array}$ & $\begin{array}{l}\text { Oh the bright } \\
\text { moon rose } \\
\text { over us } \\
\text { (L. 5) }\end{array}$ & $\begin{array}{l}\text { The natural object } \\
\text { appears in the sky } \\
\text { at night and has a } \\
\text { light }\end{array}$ & $\begin{array}{l}\text { LC: an object which its } \\
\text { body has a light and } \\
\text { appear in the night } \\
\text { SC: an object which its } \\
\text { body has a light and } \\
\text { appear in the night } \\
\text { TP: Muhammad } \\
\text { GC: - }\end{array}$ & $\begin{array}{l}\text { An-Nahl } \\
\text { (16): 41-42 }\end{array}$ \\
\hline 3. & $\begin{array}{l}\text { So Real, } \\
\text { feat. } \\
\text { Maher } \\
\text { Zain }\end{array}$ & $\begin{array}{l}\text { Allah, every } \\
\text { day I'll try to } \\
\text { be as true as I } \\
\text { can to you } \\
\text { (L. 9) }\end{array}$ & $\begin{array}{l}\text { A right fact, } \\
\text { sincere, exact, and } \\
\text { loyal }\end{array}$ & $\begin{array}{l}\text { LC: Real } \\
\text { SC: Obedient } \\
\text { TC: Obedient } \\
\text { GC: - }\end{array}$ & $\begin{array}{l}\text { Ali-Imran } \\
(3): 31\end{array}$ \\
\hline 4. & Home & $\begin{array}{l}\text { Home is } \\
\text { where that } \\
\text { heart is, }\end{array}$ & $\begin{array}{l}\text { The important } \\
\text { organ placed in } \\
\text { one's chest, }\end{array}$ & $\begin{array}{l}\text { LC: The most important } \\
\text { organ in the body } \\
\text { SC: The most important }\end{array}$ & $\begin{array}{l}\text { Al-Baqarah } \\
(2): 126\end{array}$ \\
\hline
\end{tabular}


home is where your love is (L. 10)

\section{You Are} The One

6. No One Knows But Me

7. The Path

\section{Won't you be my partner after this world?} (L. 8)

\section{People think} that I am alone, but I feel close to you (L. 17)

It's time to think and wonder why (L. 4)

\begin{abstract}
A person who takes a part in business or activity which need ones to play with, and people who are married
\end{abstract}

Near whether in space/time/relatio nship, understood, deeply involved in one activity, similar, careful, etc

To have idea, opinion, or believe, plan, attention, image in mind; to expect something, and to direct one's thought

\section{Mawlaya send your prayers and peace always forever, upon the beloved Muhammad, the more the better}

(L. 3)

9. Call on Him

A solemn request or expression to God or object of worship, a certain word of this, and the most hope
He's by your side, so have no fear

(L. 14) emotion, the central part of something, and a heart shape
A surface object
which divided by a
line, a right or left
part of person's
body, the surface
of something
which is not the
top, bottom, front and unforgettable

things/

moments/experiences

which touch one's heart

TC: The most important

and unforgettable

things/moments /

experiences which

touch one's heart

GC: -

LC: Wife/husband

Ar-Rum

SC: Wife

(30): 21

TC: -

GC: -

LC: Near in relationship

Al-Baqara

SC: Near in relationship

(2): 2-5

TC: -

GC: -

LC: To have idea of something or somebody

Ali Imran

(3): 190

SC: To have idea of something or somebody

TP: To have a deep thinking in order to find the path through any signs in the world GC: -

LC: Wish, hope, and

Al-Ahzab request

(33): 56

SC: Praise / shalawat

TP: -

GC: -

LC: Near in position

Al-Baqara

SC: Near in position

(2): 186

TC: Always presents, looks, listens of humans, and never leave them alone. GC: - 
and back, an opinion held by somebody, a particular person belong, etc

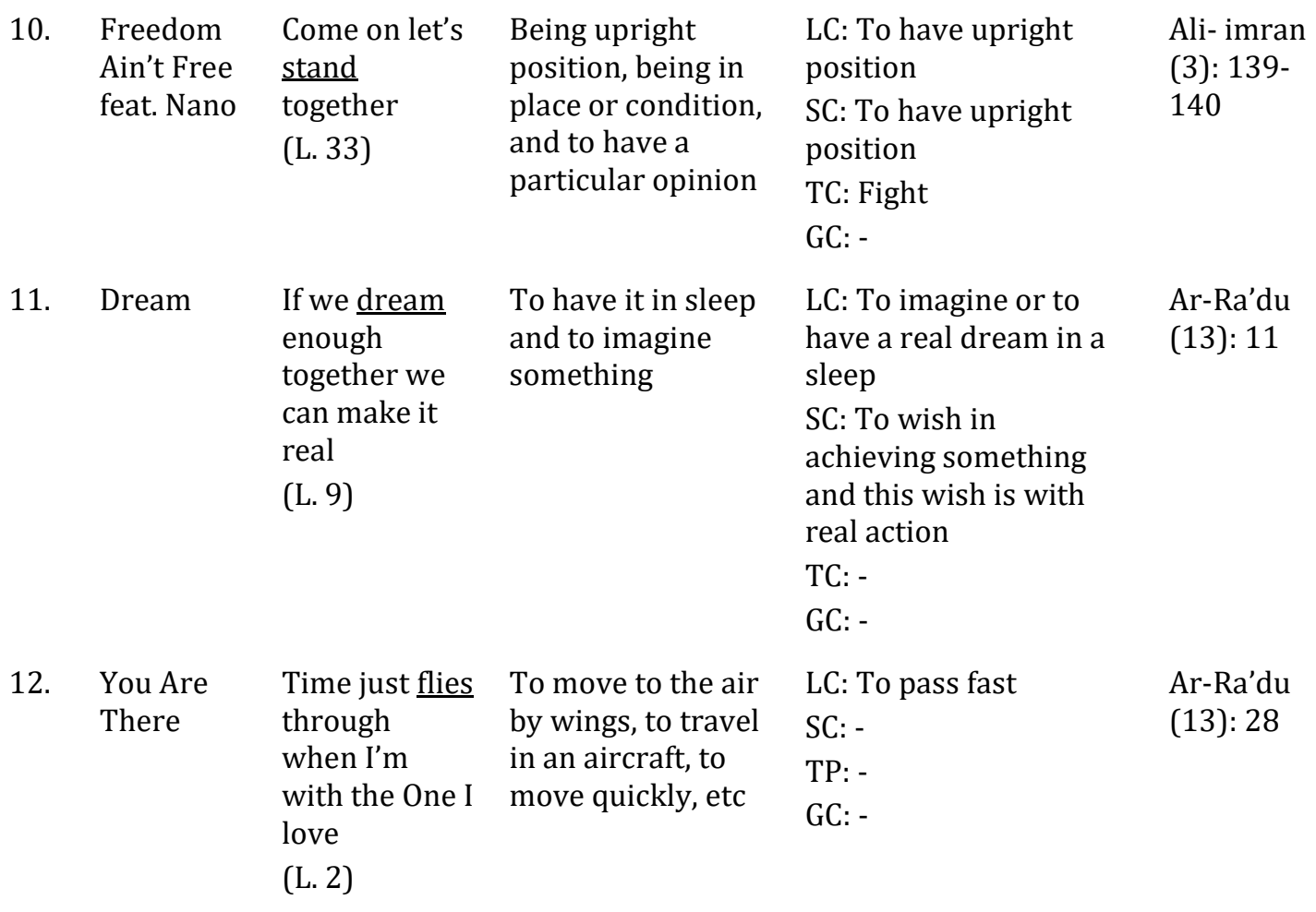

The researcher will deliver one analysis of lexical and contextual meaning, and also the Holy Qur'an values which support the lyric of song as the example of the other lyrics analysis. The result of the other lyrics has delivered through the finding above.

\section{Title : Peace and Blessings}

Lyric : His words are here to help us through

a. Lexical Meaning Analysis

Lexical meaning of 'word' is (Hornby, 2015):

1) A sound or group of sounds that expresses a meaning and forms an independent unit of language.

2) This represented as letters or symbols, usually with a space on either side.

3) Anything said, a remark, or statement.

4) Things that are said, contrasted with things that are done.

5) A promise or a guarantee.

6) A spoken command or signal.

7) The Bible and its teachings.

The KW words above are plural noun which has many multiple choices in meanings because they are obtained through lexical meaning which consists of dictionary 
meaning. When the KW stands alone, it will have meanings such as languages, utterances, promises, signals, or teachings. Those meanings are the meaning of the KW words. People who will mean the KW words lexically, surely still deliver those meanings because words could have several meanings in lexical meaning when it stands alone without any context. For example: tell me what words you speak, English or Spanish? (KW means language), I cannot hear your words, louder please! (KW means utterance), and I wish he will keep his words well (KW means promise).

b. Contextual Meaning Analysis

1) Local Context

$\operatorname{His}_{(\mathrm{LW})}$ words $_{(\mathrm{KW})} \operatorname{are}_{(\mathrm{RW} 1)}$ here $_{(\mathrm{RW})}$ to help us through

Local context is not able to find the KW words through its preceding and succeeding word. The meaning of KW is still in general. The KW words are still spoken ('his spoken are here). Since local context cannot be able to find the KW of words, the analysis in finding the meaning of the keyword will be continued to sentential context.

2) Sentential Context

Sentential context refers to next circle immediately beyond the local context and sentence is the main focus to know the intended meaning of the keyword.

\section{His words $s_{(\mathrm{KW})}$ are here to help us through}

The KW above occurs in a sentence (the researcher define a line of lyric as a sentence). When it occurs in the sentence, the meaning of words is quite clear. The KW does not only mean spoken but also teaching. This consideration based on the sentence which makes it. His spoken/teachings will help us. It is still clear and accepted enough. However, the researcher will continue to the other contexts because she doubts the intended meaning of KW above. To check it, it is better if it is continued to next context, namely topical context.

3) Topical Context

In the topical context analysis, it will use the topic which will give the big role in seeking the contextual meaning of the KW.

\section{His words $s_{(\mathrm{KW})}$ are here to help us through}

That lyric is under the title 'Peace and Blessing', and in order to know what topic of this lyric of the song is, the researcher will deliver the whole lyric of the song as follows: 


\section{Peace and Blessings}

Give me your hand I will give you my heart

Every day is a brand new start

His words are here to help us through

(Ya) Rasool Allah, peace, and blessings on you!

Chorus:

Salatullah, salamullah

'Ala Taha, Rasoolillah

Salatullah, salamullah

'Ala Yasin, Habibillah

I've never seen you but I love you so

And in your footsteps, I'll try to follow

A smile you give may stop my fall, yeah!

The Bright moon rose a mercy on all!

CHORUS

Salla Allahu 'ala Muhammad

Sallah Allahu 'alayhi wa sallam

Habibi ya Muhammad

CHORUS

Salla Allahu 'ala Muhammad

Sallah Allahu 'alayhi wa sallam

Habibi ya Muhammad

After comprehending this lyric of the song above, the researcher finds that the topic of this lyric of the song is about 'Rasulullah'. Through this topic, it will make this analysis easier in finding the contextual meaning of the KW.

\section{His words ${ }_{(\mathrm{KW})}$ are here to help us through}

'His' refers to Rasulullah. Thus, the words of Rasulullah will help us (humans). However, the next question is, 'which Rasullullah's words (spoken/teaching) will help us (humans)?' The researcher thinks that the topical context is still not enough to give the intended meaning of the KW. Thus, she decides to continue this analysis through global context.

4) Global Context

In the global context, it built up a cognitive interface between language and reality. It is about to understand: who says, what is said, to whom it is said, and information from the external world which supplies vital cues of place, time, situation, interpretation, pragmatics, discourse, demography, geography, society, culture, ethnology, and various other things. 
From the topical context, actually, there is a clue to know the intended meaning of the KW. But the KW seems still ambiguous. The question of 'which Rasullullah's words will help us (humans)?' is still not clear to decide the intended meaning of the KW.

The global context will seek the intended meaning of the KW though the external information of the keyword. The KW words which related to Rasulullah and that words are able to help humans is known as Sunnah. Raef, an Islamic music writer knows it as Sunnah, and from the Islamic literature, sunnah will help humans when they obey it.

c. The Holy Qur'an Value which supports the lyric

The Holy Qur'an value that supports the lyric of song is in Annur:

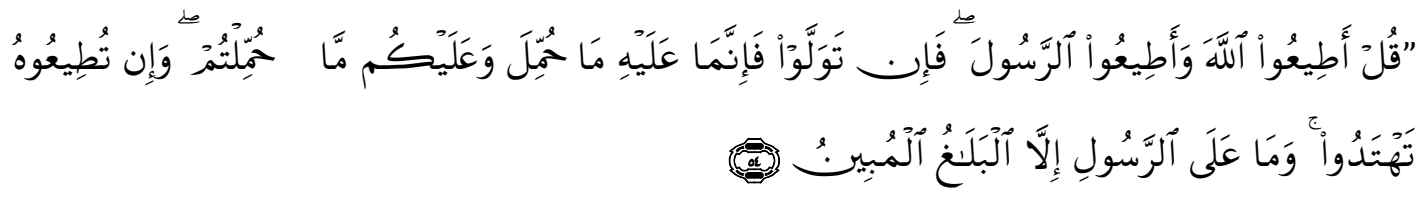

"Say: "Obey Allah, and the messenger: but if ye turn away, he is only responsible for the duty placed on him and ye for that placed on you. If ye obey him, ye shall be on right guidance. The Messenger's duty is only to preach the clear (message) (Annur (24): 54)."

That verse is talking about the obligation to obey Allah and also obey Rasulullah. The word 'obey' is repeated twice to clarify that humans have to obey Allah (His commands in the Holy Qur'an), and obeys Rasulullah (his commands, whether to do or avoid something) (Shihab, 2005: 386). If the humans turn away from Rasulullah's command, they will be loose out. On the other hand, when they obey him, they will get guidance for the happiness in the world and Hereafter. This verse supports the lyric since it talks about the obligation to obey Rasulullah and follow his step to get guidance and happiness in the world and Hereafter, and what the verse talks about is the same as the lyric content. Based on the study the researcher has done, all of Raef's song lyric of The Path album has al-Qur'an values which really good for the listener of the reader when they listen or read his lyric of the song.

\section{CONCLUSION}

Lexical meaning in Raef's song lyric The Path album which is taken from each lyric is varied. Meanwhile, the contextual meaning in Raef's song lyric The Path album in each word of each lyric is found and become the intended meaning of the keyword. In addition, the Holy Qur'an value consists in each lyric. It supports the lyric of song which will inform that each lyric has the Holy Qur'an value. 
Risalatul Hasanah, and Mosleh Habibullah, Analysis of Lexical and Contextual ...

\section{REFERENCES}

Aminuddin. (2008). Semantik: Pengantar Studi tentang Makna. Bandung: SInar Baru Algensindo.

Biek, S. M. A.-K. (2007). Ushul Fikih (F. El-Muttaqien, Trans.). Jakarta: Pustaka Amani.

Biodata Raef termasuk Profil Pribadi \& Data Keluarga-WowKeren.com. (n.d.). Retrieved June 26, 2018, from https://www.wowkeren.com/seleb/raef/profil.html\#sthash.TwF627Ls.dpuf

Dash, N. S. (2008). Context and Contextual Word Meaning. SKASE Journal of Theoretical Linguistics, 5(2), 22.

Hornby, A. S. (2015). Oxford Advanced Learner's Dictionary. Oxford: Oxford University Press.

Jannedy, S. (1994). Language File. Columbus: Ohio State University Press.

Lyons, J. (1995). Linguistic Semantics: An Introduction. Cambridge: Cambridge University Press.

Muhmidayeli. (2013). Filsafat Pendidikan. Bandung: PT. Refika Aditama.

Parera. (2004). Toeri Semantik. Jakarta: Erlangga.

Pateda, M. (2001). Semantik leksikal. Jakarta: PT. Rineka Cipta.

Raef Haggag | LinkedIn. (n.d.). Retrieved June 26, 2018, from https://www.linkedin.com/in/raef-haggag-93a11319/

Raef (singer). (2018). In Wikipedia. Retrieved from https://en.wikipedia.org/w/index.php?title=Raef_(singer)\&oldid=846161468

Shihab, M. Q. (2005). Tafsir al-Mishbah (Vol. 9). Tangerang: Lentera Hati. 